\title{
AP2B1 wt Allele
}

National Cancer Institute

\section{Source}

National Cancer Institute. AP2B1 wt Allele. NCI Thesaurus. Code C152050.

Human AP2B1 wild-type allele is located in the vicinity of $17 q 12$ and is approximately 148

$\mathrm{kb}$ in length. This allele, which encodes AP-2 complex subunit beta protein, is involved in endocytosis mediated by clathrin-coated vesicles. 